\title{
THE REPRODUCTIVE ORGANS OF THE FEMALE PLAINS VISCACHA, LAGOSTOMUS MAXIMUS
}

\author{
BARBARA J. WEIR \\ Wellcome Institute of Comparative Physiology, \\ Zoological Society of London, Regent's Park, London NW1 4RL
}

(Received 13th Fuly 1970)

\begin{abstract}
Summary. The anatomy of the reproductive organs of female plains viscacha was examined at various stages of the reproductive cycle. The ovary is peculiarly flat with deep and convoluted surface invaginations. The ripe follicle is $200 \mu \mathrm{m}$ in diameter and spontaneous ovulation of up to 800 eggs at a time takes place. True and accessory corpora lutea may be formed but it is suggested that luteinization occurs only after copulation. About seven ova are fertilized and implant, but resorption of all except the most distally situated foetus in each uterine horn occurs by Day 90 of pregnancy. No changes were detected in the uterine histology at different stages of the cycle. The cervix is not muscular but there is a longitudinal vaginal septum which extends distal to the cervical openings, causing the copulatory plug which is formed at mating to be Y-shaped. The vaginal epithelium shows changes associated with ovarian activity.
\end{abstract}

\section{INTRODUCTION}

The plains viscacha, an hystricomorph rodent related to the chinchilla, has not previously been studied in captivity (see Weir, 1971c). Owen (1839) described the anatomy of a single female and some details were given by Llanos \& Crespo (1952) in their extensive paper on the ecology of this species. The hystricomorphs so far studied (Weir, 1967) have been found to have a bicornuate uterus and a long vagina which turns sharply ventral to the vulva where there is a closure membrane. The ovaries are not encapsulated but the mesosalpinx may be extensive and the Fallopian tube has a cranial loop and distal convolutions. A characteristic feature of the hystricomorph ovary is the formation of accessory corpora lutea (cL) from luteinization of unovulated follicles. This has been described in the Canadian porcupine (Mossman \& Judas, 1949), the mountain viscacha (Pearson, 1949), the coypu (Rowlands \& Heap, 1966), the chinchilla (Weir, 1966), the acouchi (Rowlands, Tam \& Kleiman, 1970; Weir, 1971a) and the agouti (Weir, 1971b). The pattern and degree of development of the accessory CL vary in the different species and may grow so large (e.g. chinchilla) as to confuse recognition of the primary aL of ovulation. There are also species differences in other aspects of ovarian morphology; the acouchi 
has a very dense stroma (Rowlands et al., 1970) but the agouti, chinchilla and African porcupine have abundant interstitial tissue (Weir, 1967). The agouti follicle is characterized by a well-developed theca externa with very few theca interna cells (Weir, 1971b). Ovulation rate varies in the different species but only the right ovary of the mountain viscacha (Lagidium) is functional after puberty and the single young is always carried in the right uterine horn (Pearson, 1949). There is some indication in chinchilla (Chinchilla) that right ovaries are more active than left (Weir, 1967). Detailed investigation of the plains viscacha (hereinafter called viscacha) was only possible after the animals had been established in captivity.

\section{ANIMALS AND METHODS}

Animals

The viscacha colony in London was derived from forty-one animals caught in Argentina in 1967. Details of handling and husbandry have been given by Weir (1970). The daily observations for reproductive condition of the animals are

TABLE 1

ANALYSIS OF VISCACHA FEMALES USED IN THIS STUDY

\begin{tabular}{l|c|c}
\hline Reproductive state & Numbers & Range \\
\hline Immature & 23 & 0 to 60 days \\
Non-pregnant & 14 & 4 to 151 days \\
Pregnant & 24 & 2 to 49 days \\
Post partum & 6 & \\
\hline Total & 67 & \\
\hline
\end{tabular}

described by Weir (1971c) and those findings are the basis of the criteria used to deduce the reproductive status of animals used in the present study (Table 1) when they were killed or were found dead. Deaths occurred mainly from fighting amongst adults and from neglect of the young. Infections of Salmonella typhimurium or Pasturella pseudotuberculosis were a cause of death in some animals which had been fighting.

\section{Histology}

The reproductive tract was examined and some Fallopian tubes and uterine horns were flushed with physiological saline; other organs were fixed in Bouin's fluid. After embedding in paraffin wax, ovaries and some Fallopian tubes were sectioned at $5 \mu \mathrm{m}$ and every tenth section was mounted. Representative sections of vagina and uterus were cut at $4 \mu \mathrm{m}$. The routine stain used was Mayer's haemalum and eosin, but Heidenhain's azan and periodic-acid-Schiff stains were also employed. 


\section{RESULTS \\ MACROSCOPIC ANATOMY}

The tract (Pl. 1, Fig. 1) was found to be similar to that of other hystricomorphs in that the ovaries were not enclosed in a bursa, the Fallopian tube was convoluted, the uterus was bicornuate and there was a long vagina sealed at the vulva by a closure membrane, but the ovaries of the viscacha were unusual. These were flat, leaf-like structures measuring about $2.0 \times 1.0 \times 0.5 \mathrm{~cm}$ and no internal features were externally discernible. The mesovarium joined the ovary along the whole of its length. The cervix was not muscular and each uterine

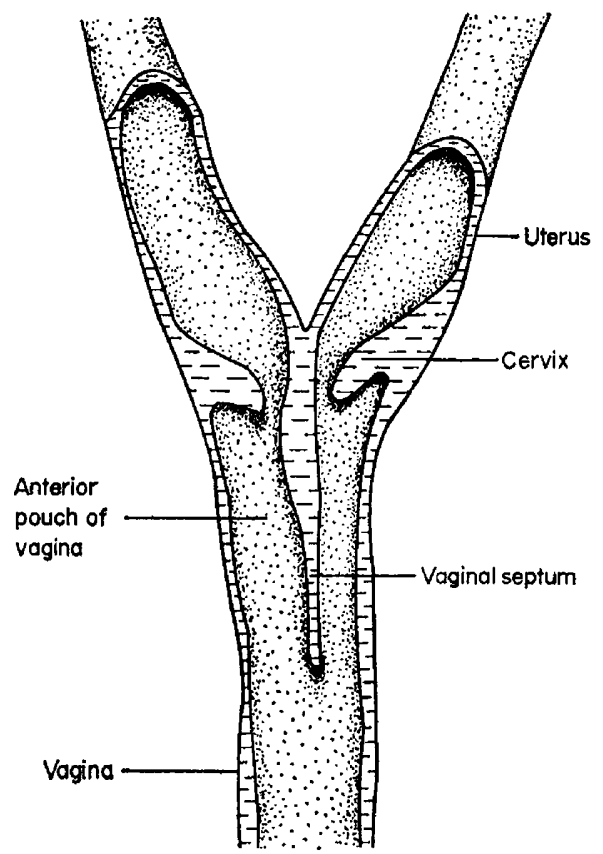

TEXT-FIG. 1. Diagram of the uterus and vagina of the viscacha to show the position of the vaginal septum. $\times 1$.

horn opened separately into the vagina. A thin longitudinal septum projected from the cervical papilla and divided the upper vagina for 2 to $3 \mathrm{~cm}$ (Textfig. 1). The conceptuses were visible from about Day 26 and the numbers seen in early pregnancy were always greater than those found nearer to term (Table 2). Usually, only two of these foetuses were brought to term and the survivors were always found in opposite horns in the position closest to the cervix. No differences in blood supply to different parts of the uterus were seen to account for the resorption which occurs at different stages in pregnancy between Day 30 and Day 80 (see Table 2 and Pl. 1, Fig. 1).

Ovary

\section{MICROSCOPIC ANATOMY}

Basic structure and cell types. A section through the ovary of a viscacha is shown 
in Pl. 1, Fig. 2. The surface appeared to be greatly convoluted and the entire ovary to be composed of long tubular strands of tissue with a central core of connective tissue. The mesovarium was thick and for much of its length was closely associated with the loops of the Fallopian tube. The deep surface invaginations were not found in foetal or neonatal ovaries but began to appear at about 6 weeks of age. Until this stage, the ovary clearly showed a cortical and medullary difference (Pl. 2, Fig. 5); the cortex was packed with oocytes, many still in nests, while primary follicles were present in the medulla. By 8 weeks of age (Pl. 2, Fig. 3), many of these follicles had more than one granulosa cell layer and the number of polyovular follicles, which was high in the neonatal ovary, was reduced. An antrum first appeared in follicles of about $150 \mu \mathrm{m}$ in diameter but antral follicles did not grow to a diameter greater than $300 \mu \mathrm{m}$. At this size, the membrana propria was prominent and the oocyte was

\section{EXPLANATION OF PLATES}

\section{PLATE 1}

Fig. 1. Reproductive tract of 47-day-pregnant viscacha. Only one (arrowed) of the seven implantations was living. The typical macroscopic appearance of the ovaries and the non-muscular cervix can be seen. $\times 1$.

Fig. 2. Section of the ovary of a viscacha which was killed in the field at about Day 115 of pregnancy. Note the bizarre structure of the ovary which contains masses of small lutein bodies and ripe follicles. Bouin, $5 \mu \mathrm{m}, \mathrm{H} \& \mathrm{E} ; \times 11.5$.

\section{PLATE 2}

Fig. 3. Part of the ovary of a 2-month-old viscacha showing the numerous oocytes and early cleft formation. Bouin, $5 \mu \mathrm{m}, \mathrm{H} \& \mathrm{E} ; \times 125$.

FIg. 4. Ripe follicle in the ovary of a viscacha which was almost at oestrus when killed. Note the prominent membrana propria and the little-developed thecae interna and externa. Bouin, $5 \mu \mathrm{m}, \mathrm{H} \& \mathrm{E} ; \times 142$.

Fig. 5. Part of the ovary of a neonatal viscacha showing cortical oocytes and several polyovular medullary follicles (arrowed). Bouin, $5 \mu \mathrm{m}, \mathrm{H} \& \mathrm{E} ; \times 62 \cdot 5$.

Frg. 6. Part of the ovary of a viscacha which was killed $12 \mathrm{hr}$ post coitum. There is a true GL on the left and two luteinizing follicles on the right; the latter will become accessory CL. Note the abundance of oocytes although this animal was known to have experienced at least seven oestrous periods. Bouin, $5 \mu \mathrm{m}, \mathrm{H} \& \mathrm{E} ; \times 115$.

Fic. 7. Part of the ovary of a 47-day-pregnant viscacha showing a cL of pregnancy (CL) and a free ovum (O). The follicle (F) from which this egg was released can be seen on the left. Bouin, $5 \mu \mathrm{m}, \mathrm{H} \& \mathrm{E} ; \times 113$.

\section{PLATE 3}

Fro. 8. Flushings from the uterus of a viscacha killed 4 days post coitum; one egg (arrowed) is two-celled. $\times 33$.

Fig. 9. Thirty-five eggs in a section of the Fallopian tube of a viscacha killed $12 \mathrm{hr}$ post coitum. Bouin, $5 \mu \mathrm{m}, \mathrm{H} \& \mathrm{E} ; \times 64$.

Fig. 10. Section of uterus of a non-pregnant viscacha; this appearance was typical for viscacha at all stages of the cycle. Bouin, $4 \mu \mathrm{m}, \mathrm{H} \& \mathrm{E} ; \times 189$.

Fig. 11. Embryo at Day 26 of pregnancy; the other five embryos were at identical stages of development although two were smaller. Bouin, $4 \mu \mathrm{m}, \mathrm{H} \& \mathrm{E} ; \times 48$.

Fig. 12. Section of vagina of 26-day-old viscacha showing columnar mucus-producing cells. Bouin, $4 \mu \mathrm{m}, \mathrm{H} \& \mathrm{E} ; \times 320$.

FIG. 13. Section of vagina of a pro-oestrous viscacha showing proliferation of cell layers. Bouin, $4 \mu \mathrm{m}$, PAS; $\times 320$.

FIG. 14. Stratification of the vaginal epithelium in an oestrous viscacha. Bouin, $4 \mu \mathrm{m}$, $\mathrm{H} \& \mathrm{E} ; \times 320$.

Fig. 15. Section of vagina of a 70-day-pregnant viscacha showing proliferation of mucusproducing cells. Bouin, $4 \mu \mathrm{m}$, PAS; $\times 320$. 
PLATE 1
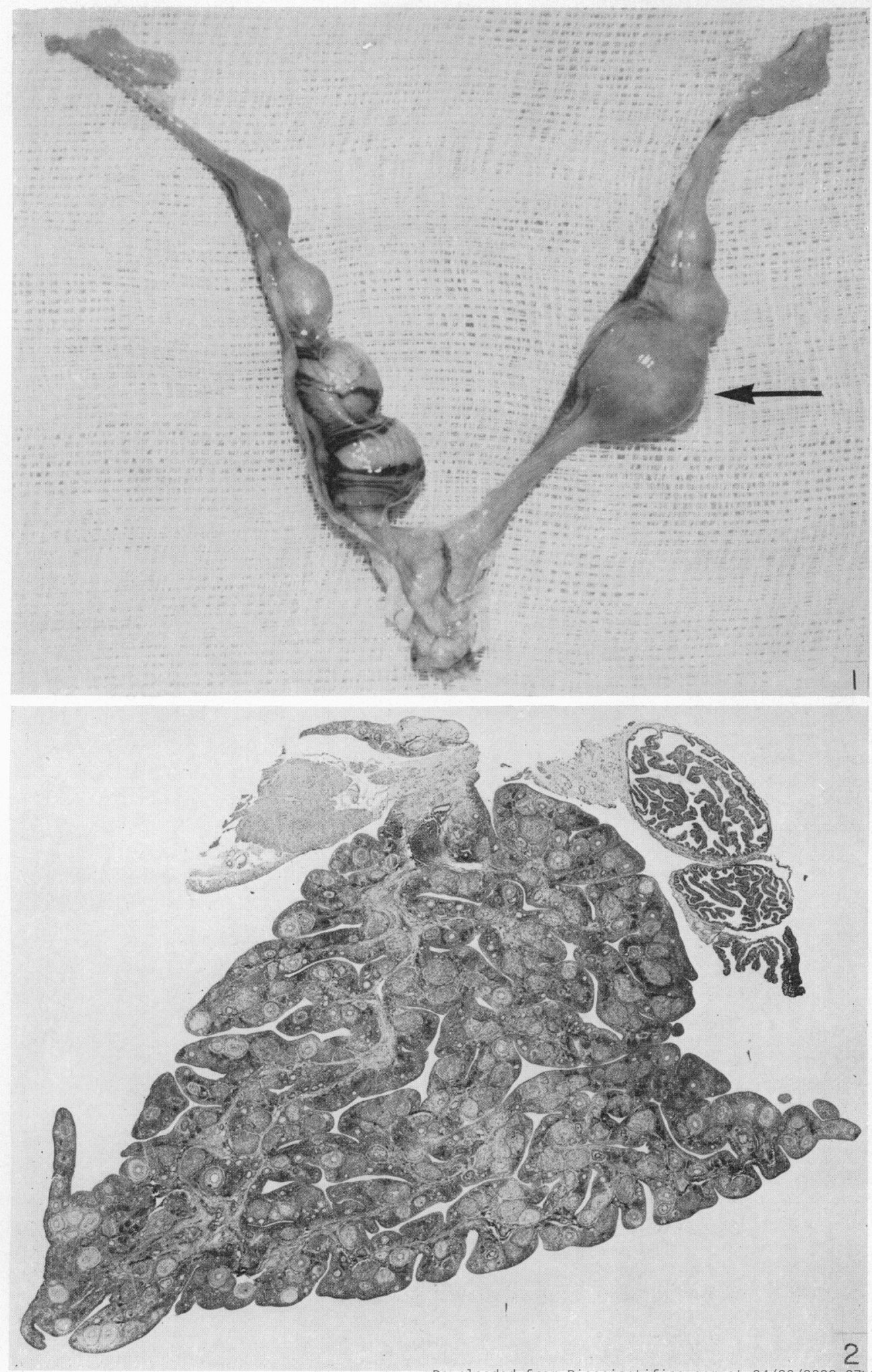
PLATE 2
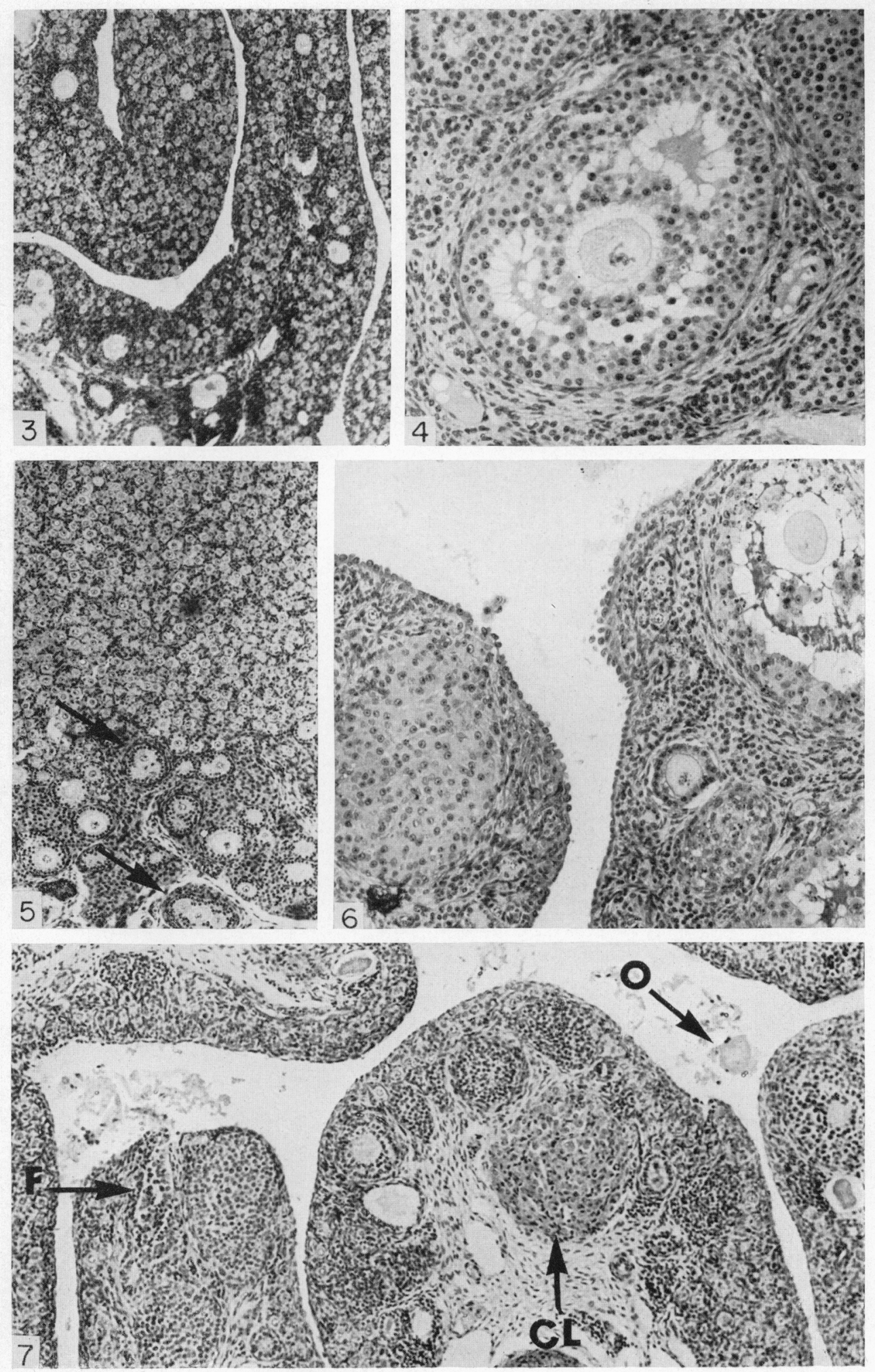
PLATE 3
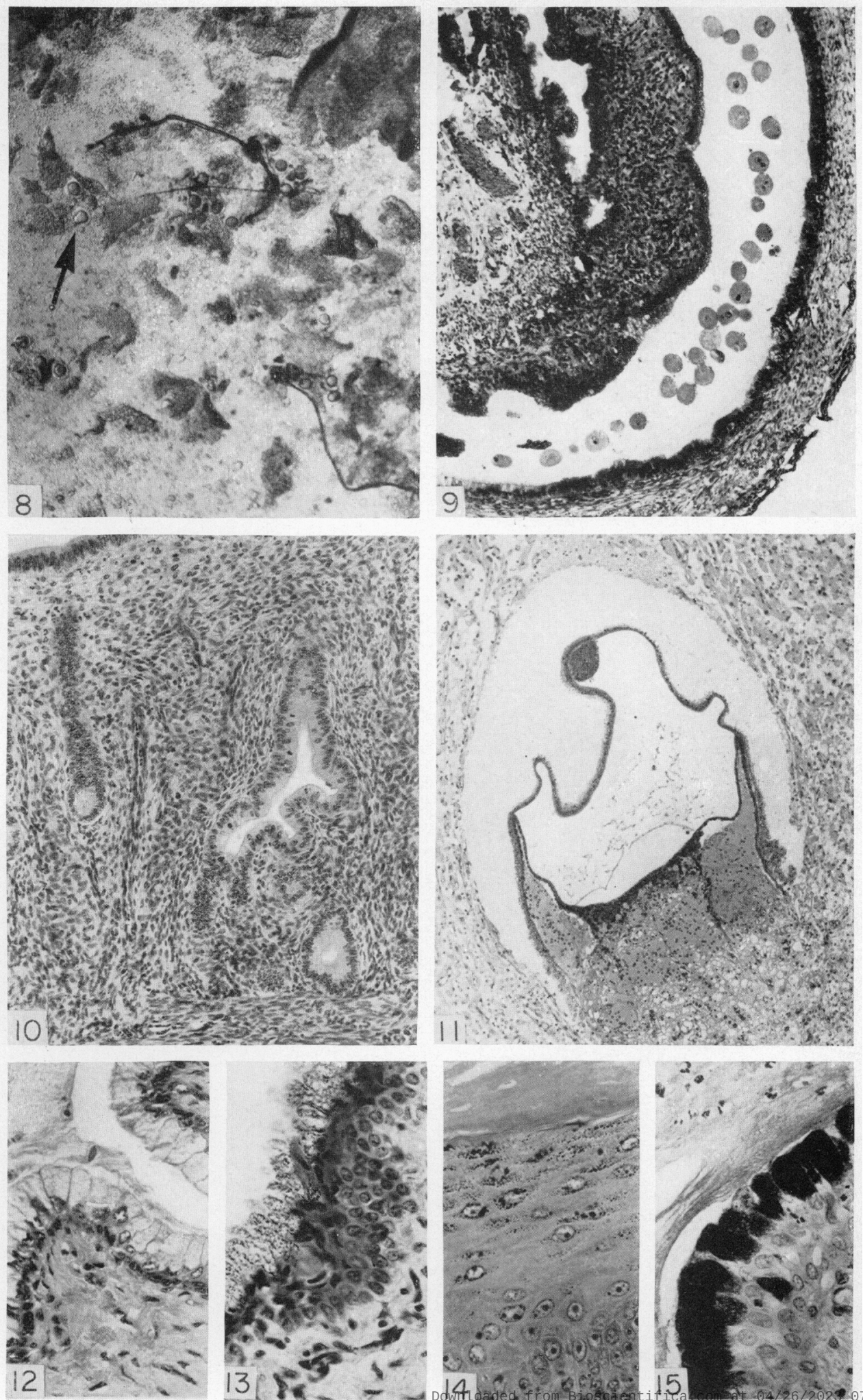
surrounded by a cumulus oophorus; the thecae externa and interna were not well developed (Pl. 2, Fig. 4). Many hundreds of mature follicles were present in pro-oestrous animals. Atresia of theca cells to interstitial cells occurred in many follicles of all sizes, and in some ovaries, appreciable amounts of interstitial tissue were present (P1. 2, Figs. 4 and 6). Luteinization of the granulosa cells also occurred in follicles which did not ovulate and zonal remains were often seen in these accessory cL (Pl. 2, Fig. 6). True cL were formed from ovulated follicles but as neither these nor the accessory CL reached diameters greater than $400 \mu \mathrm{m}$ and as both might show stigma formation, the types of $\mathrm{CL}$ were usually indistinguishable (Pl. 2, Fig. 6).

Ovarian types. When the ovaries were examined without reference to the reproductive state of the females, four distinct categories were recognized:

TABLE 2

DISTRIBUTION OF EMBRYOS IN UTERO

\begin{tabular}{|c|c|c|c|c|c|c|}
\hline \multirow{3}{*}{$\begin{array}{c}\text { Animal } \\
\text { no. }\end{array}$} & \multirow{3}{*}{$\begin{array}{c}\text { Stage of } \\
\text { pregnancy } \\
\text { (days) }\end{array}$} & \multicolumn{5}{|c|}{ No. of embryos } \\
\hline & & \multicolumn{2}{|c|}{ Resorbing } & \multicolumn{2}{|c|}{ Live } & \multirow{2}{*}{ Total } \\
\hline & & $\begin{array}{l}\text { Left } \\
\text { horn }\end{array}$ & $\begin{array}{l}\text { Right } \\
\text { horn }\end{array}$ & $\begin{array}{l}\text { Left } \\
\text { horn }\end{array}$ & $\begin{array}{c}\text { Right } \\
\text { horn }\end{array}$ & \\
\hline $\begin{array}{l}\text { V16 } \\
\text { V30 } \\
\text { V109 } \\
\text { V70 } \\
\text { V9 } \\
\text { V22 } \\
\text { V5 } \\
\text { V61 } \\
\text { V21 } \\
\text { E130 } \\
\text { V37 } \\
\text { E122 } \\
\text { V42 } \\
\text { V36 } \\
\text { V27 }\end{array}$ & $\begin{array}{r}26 \\
28 \\
47 \\
67 \\
71 \\
71 \\
\text { about } 85 \\
90 \\
104 \\
106 \\
106 \\
\text { about } 110 \\
113 \\
\text { about } 115 \\
133 \\
140 \\
\text { (Late) }\end{array}$ & $\begin{array}{l}2 \\
1 \\
1 \\
1 \\
1\end{array}$ & $\begin{array}{l}4 \\
3 \\
1 \\
2 \\
1\end{array}$ & $\begin{array}{l}3 \\
3 \\
1 \\
1 \\
1 \\
1 \\
1 \\
1 \\
1 \\
1 \\
1 \\
1 \\
1 \\
1\end{array}$ & $\begin{array}{l}3 \\
2 \\
1 \\
1 \\
1 \\
1 \\
1 \\
1 \\
1 \\
1 \\
1 \\
1 \\
1\end{array}$ & $\begin{array}{l}6 \\
5 \\
7 \\
6 \\
4 \\
2 \\
5 \\
3 \\
2 \\
2 \\
2 \\
2 \\
2 \\
1 \\
1\end{array}$ \\
\hline
\end{tabular}

(i) All the immature females had ovaries which contained no mature follicles and no cL. Although follicular layers were present around medullary follicles from birth, antral follicles were not present at 2 months of age. None of the seven adult females which had this type of ovary were pregnant although two animals were 14 and 18 days post partum. Two females had closed vaginal membranes; the other three were all known to have been recently in oestrus but no evidence of mating had been found.

(ii) Six animals had ovaries containing mature follicles and no cL. The conceptus of one of these animals was in the last stages of resorption and the lack of CL may have been the cause for this failure of pregnancy. Two females had vaginal closure membranes which had been perforate for only 2 and 5 days respectively and were probably pro-oestrous. The other three animals had closed vaginae but may have been approaching oestrus. This was certainly likely for one that was 25 days post partum and was not suckling. 
(iii) Ovaries with cL but with no mature follicles were found in eight animals, all except one of which were known to have mated at varying times (12 hr to 28 days) before death.

(iv) Twenty-one viscacha had ovaries containing mature follicles and CL including eighteen of the twenty-four pregnant females. The other three animals were suckling.

\section{Ovulation and fertilization}

The inability always to distinguish between GL and accessory CL and the complexity of the ovary prevented an accurate count of ovulated follicles to determine ovulation number. In eleven viscacha, two to seven ova were found in the ovarian clefts (Pl. 2, Fig. 7). Since there were known to be at least seven conceptuses, it was at first thought that these ova might represent the ovulation number for the species, but nine of these eleven viscacha were known to be already pregnant. The number of eggs ovulated by the viscacha was, therefore, determined by counting the eggs found in serial sections of (Pl. 3, Fig. 9) or

TABLE 3

NUMBERS OF EGGS RECOVERED FROM PLAINS VISCACHA

\begin{tabular}{|c|c|c|c|c|c|c|}
\hline \multirow{2}{*}{$\begin{array}{l}\text { Animal } \\
\text { no. }\end{array}$} & \multirow{2}{*}{$\begin{array}{c}\text { Time } \\
\text { post coitum }\end{array}$} & \multicolumn{3}{|c|}{ No. of eggs } & \multirow[t]{2}{*}{ Situation } & \multirow[t]{2}{*}{ Comment } \\
\hline & & Left & Right & Total & & \\
\hline V4 & $12 \mathrm{hr}$ & $449 \mathrm{~s}$ & $396 \mathrm{~s}$ & 845 & $\begin{array}{l}\text { Fallopian } \\
\text { tube }\end{array}$ & Probably none fertilized \\
\hline V82 & ?24 hr & $55 \mathrm{f}$ & $197 \mathrm{~s}$ & 252 & $\begin{array}{l}\text { Fallopian } \\
\text { tube }\end{array}$ & $\begin{array}{l}\text { All with polar bodies but } \\
\text { fertilization not detected }\end{array}$ \\
\hline V151 & 4 days & $134 \mathrm{~s}$ & $179 \mathrm{f}$ & 303 & $\begin{array}{l}\text { Fallopian } \\
\text { tube }\end{array}$ & $\begin{array}{l}\text { Ova flushed: } \\
3 \text { two-celled } \\
38 \text { fragmenting } \\
138 \text { unfertilized }\end{array}$ \\
\hline V136 & 6 days & $16 \mathrm{f}$ & $34 \mathrm{f}$ & 50 & Uterus & $\begin{array}{l}\text { Ova flushed: } \\
5 \text { four-celled } \\
45 \text { fragmenting }\end{array}$ \\
\hline
\end{tabular}

$s=$ sectioned $f=$ flushed.

flushings from (Pl. 3, Fig. 8) Fallopian tubes of viscacha known to have been in oestrus. These examinations gave the egg counts shown in Table 3. Although there was a tremendous range, probably due to differences of technique, timing, and loss into the peritoneal cavity, the ovulation rate in this species is considered to be very high. When oocytes retained in luteinized follicles are also taken into account, the total egg loss at each oestrus can be reckoned as being of the order of several hundreds. Fertilization occurred in the Fallopian tube but very few of the large numbers of eggs appeared to have been fertilized (Table 3).

\section{Uterus}

No gross changes in uterine histology were observed when considered with the various ovarian conditions. Most uteri appeared similar to that shown in Pl. 3, 
Fig. 10. At Day 24 of pregnancy, implantation had been achieved, but the decidual reaction was hardly visible at first examination of the uterus. At Days 26 and 28, the decidual swellings were well formed and all the conceptuses appeared to be at identical stages of development (Pl. 3, Fig. 11) although two were already smaller than the others.

\section{Vagina}

The epithelium of the vagina was found to vary according to the reproductive state of the animal. In the neonatal to prepubertal viscacha, the epithelium was one or two cells thick, the luminal layer being of columnar mucus-producing cells (P1. 3, Fig. 12). In pro-oestrus, proliferation of cell layers and early stratification was seen (Pl. 3, Fig. 13), and this developed further in oestrus (Pl. 3, Fig. 14). After ovulation and sloughing of the vaginal cornified sheath, the epithelium appeared similar to that in pro-oestrous animals, but no mucus was present. The mucous cell layer next to the lumen was re-formed before the next oestrus and proliferation of this layer occurred in pregnancy (P1. 3, Fig. 15).

\section{DISCUSSION}

The most striking feature of the reproductive organs of the female plains viscacha is the bizarre ovary, although Owen (1839) stated that there was 'nothing remarkable in the ovaria or Fallopian tubes'. Harrison \& Harrison Matthews (1950), who discussed the occurrence of crypts in the ovaries of several mammalian species, described them as invaginations of the germinal epithelium through the tunica albuginea. However, in the viscacha ovary, the invaginations involve both the germinal epithelium and the tunica albuginea and are quite unlike those found in other mammalian species because they penetrate through the cortex into the medulla and are much more extensive. No reasons can be adduced for this phenomenon since the viscacha's two living relatives, the mountain viscacha and the chinchilla, both have the more normal mammalian type of solid ovary. But peculiarities of reproductive physiology have been described in these species. The mountain viscacha ovulates only from the right ovary (Pearson, 1949) while numerous accessory cL are found in both species (Weir, 1966). The viscacha also develops accessory cL but the relative numbers of each in this species have not been determined. At least $25 \%$ and probably about $50 \%$ of ova are lost by luteinization of the follicle before ovulation can occur, and together with the high ovulation rate of 200 to 800 eggs, upwards of 1000 oocytes may be lost at each oestrus. This is an extraordinarily high number for a mammal and far exceeds that of the elephant shrew, Elephantulus myurus (Family Macroscelididae) which ovulates 50 to 150 eggs (Van der Horst \& Gillman, 1941). It is interesting to speculate whether there is a reduced rate of degeneration of primordial oocytes in viscacha since, although the numbers of oocytes in the neonatal ovary appear to be great, oocytes are still plentiful in the ovaries of animals known to have had at least seven ovulation periods (Pl. 2, Fig. 6). Elephantulus myurus still has a structurally typical mammalian ovary although the cL are everted and tend to fuse together after ovulation. However, the diameter of the mature follicle is slightly smaller in 
E. myurus than in species such as $E$. intufi which do not polyovulate (Tripp, 1970). This suggests the evolutionary path which may have been followed by the viscacha; firstly, reduction in the size of the ovulatory follicle, and secondly, extreme alteration of the ovarian structure to increase the surface area for ovulation without increasing the gross size of the ovary itself. The evolutionary significance of polyovulation can only be guessed at; it may be a method of providing a large gene pool for variation, but if this were selectively advantageous, it is surprising that no other mammalian species are known to have evolved in this direction.

In the viscacha, ovulation probably takes place spontaneously after the vagina has been open for several days, but luteinization of the ruptured and unruptured follicles may not always occur. This seems to be the only explanation for those females which were known to have been in oestrus but did not have either mature follicles or CL in the ovaries. It was not known whether these females had or had not copulated, although all had the opportunity, but those females which were known to have mated had luteinized follicles in the ovaries. A possible explanation for the suggestion that ovulation is spontaneous and luteinization is induced could be that the inherent life of the CL is too long for the ovarian 'build-up' for the next ovulation. Certainly the CL persist throughout the 155day pregnancy and the ovaries seem to be essential for the maintenance of gestation (Weir, unpublished observations). In the guinea-pig, the presence of CL are a bar to natural ovulation (Rowlands, 1956), but this is not so in some other hystricomorphs (Weir, 1967, 1969, 1971 a, b). Moreover, mature follicles as well as CL are found in the ovary of the pregnant viscacha and ovulation appears to take place throughout gestation. The ova found in the 'interstices' of these ovaries were all healthy and many were surrounded by cumulus. It is unlikely that these had remained from the ovulation period which gave rise to the pregnancy. Free ova were not seen in the ovaries of females in which eggs were found in the tubes or uterus after ovulation; this seems to preclude any regular accumulation of ova in the clefts of the ovary.

In spite of the high ovulation rate, the number of eggs actually fertilized appears to be low. It is possible that the observed two- and four-cell stages were fragmenting eggs, especially as no supernumerary spermatozoa were seen in the zonae pellucidae. The similarity between the numbers of apparently fertilized eggs and the implantations suggests that only this low number is fertilized. Thus, the viscacha differs from the elephant shrew where the majority of the eggs shed are fertilized (Tripp, 1970). However, E. myurus has an anatomically distinct portion of the uterus, the implantation chamber (Van der Horst \& Gillman, 1941), and only the two zygotes that succeed in implanting here actually survive to term. No such differences were found in viscacha, where all the fertilized eggs probably implant and resorption occurs early in pregnancy, long before there can be any question of crowding in the uterus. The regularity of resorption in the viscacha suggests that this species could be useful for laboratory studies on this phenomenon.

The lack of a muscular cervix in a species which bears such well developed young is surprising, but the mara, Dolichotis patagona (Weir, unpublished observations) also manages without a muscularized cervix. Owen (1839) commented 
on the longitudinal septum which divides the viscacha vagina for "about an inch" beyond the cervical openings and the presence of this structure has been confirmed. The septum effectively produces anterior vaginal pouches and when the ejaculate of the male is extruded as the copulatory plug, the vaginal epithelium of this anterior end is also sloughed, thus forming a Y-shaped copulatory plug (see Pl. 1, Fig. 2, Weir, 1971c). It was suggested by Owen (1839) that the vaginal septum is a primitive feature because it is rudimentary in some other placental mammals and is similar to an analogous structure in the marsupial reproductive tract. The viscacha may have retained the vaginal septum and the ovary as primitive tetrapod features, but it is strange that it should have done so while evolving in the same way as other hystricomorphs in many other aspects of its reproductive physiology. It is also strange that neither the related chinchilla nor the mountain viscacha resemble the plains viscacha in the complexity of the reproductive organs.

\section{ACKNOWLEDGMENTS}

My thanks are due to Dr I. W. Rowlands for his constant encouragement and assistance in flushing the tracts for eggs. The study was financed by the Ford Foundation but generous support for the collection of the animals in South America was given by the Royal Society, the Medical Research Council and the Wellcome Trust. The photographs were taken on a Zeiss Ultraphot microscope provided by the Wellcome Trust.

\section{REFERENCES}

Harrison, R. J. \& Harrison Matthews, L. (1950) Sub-surface crypts in the cortex of the mammalian ovary. Proc. zool. Soc. Lond. 120, 699.

Llanos, A. C. \& Crespo, J. A. (1952) Ecologia de la vizcacha (Lagostomus maximus maximus Blainv.) en el nordeste de la provincia de Entre Rios. Revta Invest. agric. B. Aires, 6, 289.

Mossman, H. W. \& Judas, I. (1949) Accessory corpora lutea, luteal cell origin and the ovarian cycle in the Canadian porcupine. Am. F. Anat. 85, 1.

Owen, R. (1839) Notes on the anatomy of the Biscacha (Lagostomus trichodactylus Brookes). Proc. zool. Soc. Lond. p. 175.

Pearson, O. P. (1949) Reproduction of a South American rodent, the mountain viscacha. Am. $\mathcal{F}$. Anat. 84, 143.

Rowlands, I. W. (1956) The corpus luteum of the guinea-pig. Ciba Fdn Colloq. Ageing, 2, 69.

Rowlands, I. W. \& Heap, R. B. (1966) Histological observations on the ovary and progesterone levels in the coypu (Myocastor coypus). Symp. zool. Soc. Lond. 15, 335.

Rowlands, I. W., TAM, W. H. \& Kleiman, D. G. (1970) Histological and biochemical studies on the ovary and of progesterone levels in the systemic blood of the green acouchi (Myoprocta pratti). 7. Reprod. Fert. 22, 533.

Tripp, H. R. H. (1970) Reproduction in the Macroscelididae with special reference to ovulation. Ph.D. thesis, University of London.

Van der Horst, C. J. \& Gillman, J. (1941) The numbers of eggs and surviving embryos in Elephantulus. Anat. Rec. 80, 443.

WEIR, B. J. (1966) Aspects of reproduction in chinchilla. 7. Reprod. Fert. 12, 410.

WEIR, B.J. (1967) Aspects of reproduction in some hystricomorph rodents. Ph.D. thesis, University of Cambridge.

WeIR, B. J. (1969) The induction of ovulation in the chinchilla. J. Endocr. 43, 55.

WEIR, B. J. (1970) The management and breeding of some more hystricomorph rodents. Lab. Anim. $4,83$.

WEIR, B. J. (197la) Some observations on reproduction in the female green acouchi, Myoprocta pratti. 7. Reprod. Fert. 24, 193.

WEIR, B. J. (1971b) Some observations on reproduction in the female agouti, Dasyprocta aguti. J. Reprod. Fert. 24, 203.

Werr, B. J. (1971c) The reproductive physiology of the plains viscacha, Lagostomus maximus. F. Reprod. Fert. 25, 355. 